\title{
Fugitive Aerosol Therapy Emissions during Mechanical Ventilation: In Vitro Assessment of the Effect of Tidal Volume and Use of Protective Filters
}

\author{
Ciarraí O'Toole ${ }^{1 *}$, James A. McGrath ${ }^{1}$, Mary Joyce² ${ }^{2}$ Gavin Bennett ${ }^{2}$, Miriam A. Byrne ${ }^{1}$, \\ Ronan MacLoughlin ${ }^{2,3,4}$
}

${ }^{1}$ School of Physics \& Ryan Institute's Centre for Climate and Air Pollution Studies, National University of Ireland Galway H91 CF50, Galway, Ireland

${ }^{2}$ Aerogen, IDA Business Park, Dangan, H91 HE94, Galway, Ireland

${ }^{3}$ School of Pharmacy and Biomolecular Sciences, Royal College of Surgeons, D02 YN77, Dublin, Ireland

${ }^{4}$ School of Pharmacy and Pharmaceutical Sciences, Trinity College, D02 PN40, Dublin, Ireland

\begin{abstract}
Background: During mechanical ventilation of a patient requiring ventilatory support, bystanders could potentially be exposed to aerosolised drug. Methods: Fugitive drug aerosol emissions during simulated adult mechanical ventilation was assessed on a dual limb circuit. Tidal volume was set at $270 \mathrm{~mL}$ and $820 \mathrm{~mL}$. The use of a protective filter on the exhalation port of the mechanical ventilator was assessed. Results: Higher fugitive aerosol mass concentrations in the local environment were associated with larger tidal volume $\left(0.077(0.073,0.091) \mathrm{mg} \mathrm{m}^{-3}\right.$ at $\mathrm{V}_{\mathrm{t}}=820 \mathrm{~mL}$ vs. $0.062(0.056,0.065) \mathrm{mg} \mathrm{m}^{-3}$ at $\mathrm{V}_{\mathrm{t}}$ $=270 \mathrm{~mL}$ ) when no protective filter was used. The range of mass median aerodynamic diameters recorded was from 0.93 to $2.96 \mu \mathrm{m}$. When a filter was placed on the exhalation port of the mechanical ventilator, no fugitive emissions were recorded. Conclusion: This study confirms that an appropriate filtration protocol mitigates the risk of fugitive emissions being released when patients undergo aerosol therapy during mechanical ventilation. A larger tidal volume resulted in higher fugitive aerosol mass.
\end{abstract}

Keywords: Aerosols; Protective filters; Exposure; Fugitive; Exhaled air.

\section{INTRODUCTION}

Mechanical ventilation is a mainstay in the provision of ventilatory support in respiratory patients in receipt of critical care, delivering oxygen and maintaining airway pressures. It can be administered non-invasively, via tight fitting facemask or hood, or invasively via a tracheostomy or endotracheal tube.

In the normal treatment of the mechanically ventilated patient, concurrent aerosol therapy is common. Typical medications administered as an aerosol include, but are not limited to; bronchodilators, antibiotics, antivirals, antiinflammatories and, less frequently, hypertonic saline for maintenance of mucociliary clearance. The most commonly used aerosol generators in the ICU are nebulisers (Ehrmann et al., 2016). Nebulisers convert liquid solutions or suspensions into a respirable aerosol, which is then delivered to the patient lung during the inspiratory phase of ventilation. Previous studies have identified factors affecting aerosol drug delivery

\footnotetext{
* Corresponding author.

Tel.: +35391495289

E-mail address: c.otoole9@nuigalway.ie
}

during mechanical ventilation (ventilation mode, nebuliser type, gas flow, position in the circuit, dose etc.), and with varying patient profiles (Dhand, 2008; Guerin et al., 2008; Ari et al., 2010; Dugernier et al., 2016; Berlinski and Velasco, 2019). However, even with the combination of all optimal factors, it is clear that not all of the drug deposits in the patient lung, and the majority is lost down the expiratory limb, towards the ventilator, and potentially to the local environment (Rau et al., 2004; Dugernier et al., 2016). Importantly, the component released to the local environment has not been studied in detail.

In disparate fields of study, reports have focused on the health impacts upon healthcare workers (HCWs) in their chosen fields; for example, it has been found that nurses have twice the risk of developing asthma compared with other occupations (Arif et al., 2009). Chughtai et al. (2013) showed that airborne medical aerosols are an occupational hazard to HCWs and homecare workers. Tsai et al. (2015) highlighted the lack of knowledge among respiratory therapists with $52 \%$ of therapists never receiving training for administering antibiotics. Few have quantified the secondary impact that respiratory therapy could have on $\mathrm{HCW}$ and bystander health, however, one recent study has attempted to set occupational exposure limits for commonly aerosolised drugs (Frank et al., 2019). 
One experimental approach that has been used is intrapulmonary smoke particles and a laser light sheet to investigate the exhaled air from a patient during non-invasive ventilation with helmets, total facemask and oronasal facemask (Hui et al., 2006; Lin et al., 2009; Hui et al., 2015; Hui et al., 2019). These studies focused on a visual approach and did not obtain quantitative data regarding fugitive emissions. Recent studies have proceeded to quantify aerosol mass concentrations of fugitive emissions from various nebulisers and patient interfaces including; facemasks, mouthpiece combination, nasal cannula and tracheostomy reporting mass fugitive emissions as high as $0.370 \pm$ $0.046 \mathrm{mg} \mathrm{m}^{-3}$ (Elmashae et al., 2019; McGrath et al., 2019a, b; Oilier et al., 2019). It is evident from these studies that aerosol is emitted into the surrounding environment when a patient undergoes respiratory therapy, and secondary exposure is a factor for HCWs and bystanders to consider.

A single study to date (Ari, 2016) has investigated, by indirect means, the potential for aerosol to escape during mechanical ventilation, through the collection of drug deposited at the exhalation port of the mechanical ventilator with and without filters. When no filter was present, a 160fold higher amount of drug was deposited at the exhalation outlet than in the case where an expiratory filter was present. From these findings, it was concluded that HCWs and bystanders have a second-hand exposure risk to escaped aerosol of potentially greater than $45 \%$ of the nominal dose placed in the nebuliser. A limitation of this study was that airborne drug concentration was not examined, and the potential for fugitive emissions was only deduced based on the proportion of drug on the filter. A recent narrative review from our group details the current state of the art knowledge with respect to fugitive medical aerosols from all patient interventions in the intensive care environment (O'Toole $e t$ al., 2020).

In response to the current SARS-COV-2 pandemic, several international expert consensus recommendations call out for additional protective measures, including the use of closed circuit nebulisers (American Association for Respiratory Care, 2020; Cinesi Gómez et al., 2020; Cook et al., 2020).

Factors that are likely to affect fugitive emissions in a mechanical ventilation system, and which have not been studied via detailed aerosol analysis in other research, include tidal volume, and additionally, the presence or absence of exhalation port filters. To redress this, the current study focuses on analysing fugitive nebuliser-generated medical aerosol emissions during simulated adult mechanical ventilation, and investigates the effect of tidal volume, as well as exhalation port filter presence/absence, on fugitive emissions. Furthermore, the potential for exposure to fugitively-emitted aerosol is evaluated. The study's hypothesis is that, placing a filter on the exhalation port of the mechanical ventilator reduces fugitive emissions and that an increase in tidal volume increases fugitive emissions.

\section{METHODOLOGY AND MATERIALS}

\section{Nebuliser}

Experiments were performed using the Aerogen Solo closed circuit vibrating mesh nebuliser (Aerogen Ltd, Galway, Ireland). The nebuliser performance characteristics, measured using laser diffraction (Spraytec, Malvern Instruments, Malvern, United Kingdom) as previously described (MacLoughlin et al., 2009) are outlined in terms of average droplet size (4.56 $\mu \mathrm{m}$ Volumetric Mean Diameter) and aerosol flow rate $\left(0.32 \mathrm{~mL} \mathrm{~min}^{-1}\right)$. A $2 \mathrm{~mL}$ dose of the bronchodilator, albuterol sulphate (consisting of water, salt, hydrochloric acid and albuterol sulphate) $\left(2 \mathrm{mg} \mathrm{mL}^{-1}\right)$, was nebulised as a tracer aerosol for each individual run (International Organization for Standardization, 2019).

\section{Mechanical Ventilator and Interfaces}

A critical care mechanical ventilator (Bellavista 1000, IMT Medical, Buchs, Switzerland) was used to simulate ventilation of an adult patient (SmartLung 2000, IMT Medical, Buchs, Switzerland) (Fig. 1). An active humidification system (MR850, Fisher \& Paykel, New Zealand) was used. In line with clinical practice in some institutions, and in accordance with manufacturer-provided options, the nebuliser was placed on the inspiratory limb, before the wye (Moraine et al., 2009; Berlinski and Willis, 2013; Aerogen Ltd., 2016). The ventilator was operated at two tidal volumes of 270 and $820 \mathrm{~mL}$ (approximately $4 \mathrm{~mL}$ per $\mathrm{kg}$ and $12 \mathrm{~mL}$ per $\mathrm{kg}$ respectively, based on a standard $69 \mathrm{~kg}$ adult (The Acute Respiratory Distress Syndrome Network, 2000), and the preferred ventilatory approach for Acute Respiratory Distress Syndrome (ARDS) and SARS-COV-2 patients. All other ventilator settings remained constant; Adult setting, Mode $=$ Volume controlled ventilation $(\mathrm{VCV})$, PEEP = 5 mbar, breathing rate $=15 \mathrm{BPM}$ and $\mathrm{I}: \mathrm{E}=1: 2$ ).

\section{Filters}

Two different filters were assessed, a single membrane filter (SMF), the Respirgard II filter (303; Vital Signs Division of CareFusion, San Diego, USA), and a pleated hydrophobic filter (PHF), the Pall Breathing Circuit Filter (BB-50T; Pall Biomedical Products, Port Washington, USA). These filters were placed on the exhalation port of the ventilator during testing. Current literature states that the Respirgard II 303 is an absolute filter with an efficiency of 99.9\% for bacterial and $99.8 \%$ for viral for particles $\geq 0.3 \mu \mathrm{m}$ (Demers et al., 2016). The Pall BB-50T has a higher efficiency with $99.9 \%$ for bacterial and viral at a particle size of $0.20 \mu \mathrm{m}$ or greater (Demers et al., 2016). The SMF is used in clinical and home care settings, and the PHF is considered a highly efficient filter providing additional filtration intended, primarily, for protection of the mechanical ventilator (Demers et al., 2016).

\section{Environmental Temperature and Humidity}

Temperature and humidity were measured using a TG502 multi-Gad PID meter (GrayWolf, Shelton, USA). Temperature and humidity were calculated to ensure no abnormal environmental conditions were present during the experiment and that tests reflected standard respiratory treatment conditions. Temperature and humidity readings were taken at the start and end of the experiment, and readings were averaged over all runs. 


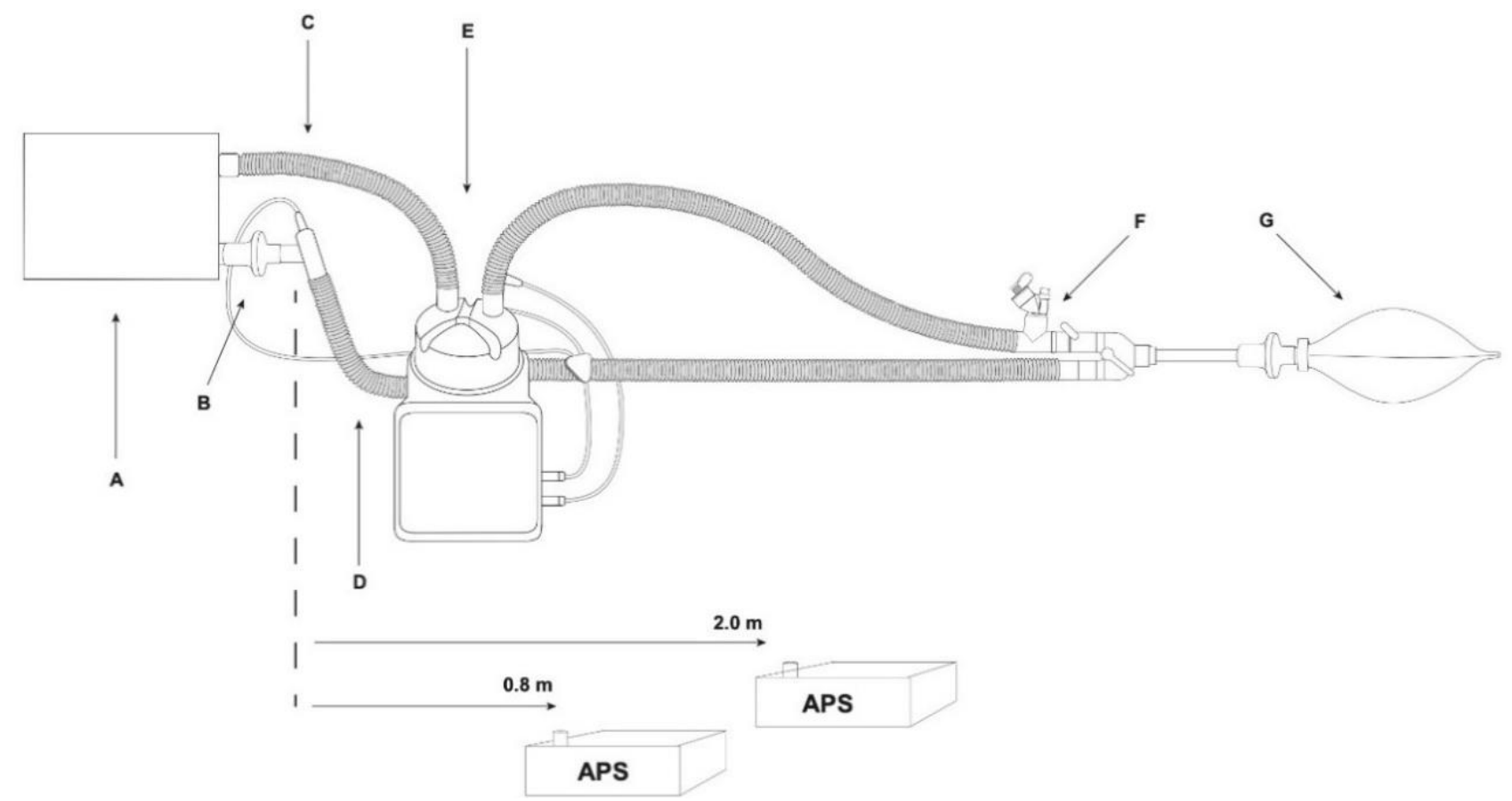

Fig. 1. Illustration of experimental set up (not to scale). A - Mechanical ventilator, B - Expiratory Filter, C - Inspiratory limb, D - Expiratory limb, E - Humidifier, F - Vibrating Mesh Nebuliser, G - Test Lung.

\section{Airflow Characteristics}

Mass concentrations and size distributions were recorded using two Aerodynamic Particle Sizers (APS) (APS, model 3321, TSI Inc., ST. Paul, Minnesota, USA) at two different distances from the ventilator $(0.8 \mathrm{~m}$ and $2.0 \mathrm{~m})$. These distances were chosen to represent a caregiver at the bedside $(0.8 \mathrm{~m})$ and to represent a "bystander", who could be a patient in an adjacent bed or standing nearby $(2.0 \mathrm{~m})$ (Fig. 1). The APS recorded data for a total of 30 minutes; the first five minutes focussed on ambient concentrations (pre-nebulisation), followed by 10 minutes of nebulisation and then the remaining time monitored the aerosol decay period within the room. It should be noted that the APS has a limit of detection of $0.5 \mu \mathrm{m}$. The laboratory room in which the study was conducted had dimensions $\mathrm{L}=6.06 \mathrm{~m}, \mathrm{~W}=2.70 \mathrm{~m}$ and $\mathrm{H}=2.71 \mathrm{~m}$. The air change rate was calculated to be approximately $0.65 \mathrm{~h}^{-1}$.

\section{Characterising Aerosol Mass Concentrations}

Prior to each test, the room was ventilated for approximately 30-45 minutes to achieve ambient aerosol concentrations. Once a full 30-minute study run was completed, data was extracted from the APS's to quantify aerosol mass concentrations, particle number concentration, and size distribution (based on both particle number and particle mass). Aerosol mass concentration is relevant to the estimation of inhaled dose of fugitively-emitted drug by a caregiver/bystander, and particle number concentration better represents the smaller end of the size distribution of emitted aerosol particles. A total of 48 runs were carried out (Fig. 2). Thirty-six runs investigated the effects of tidal volume (18 at each volume), while 12 runs examined the influence of filters. Individual experiments were run consecutively, once monitoring showed that the laboratory air contained ambient aerosol levels.

\section{Potential Inhalation Exposure}

Potential inhalation exposure of a healthcare worker was calculated over a 30-minute period excluding ambient levels and based on average nebulisation for $\mathrm{V}_{\mathrm{t}}=820 \mathrm{~mL}$ and $\mathrm{V}_{\mathrm{t}}=$ $270 \mathrm{~mL}$. The breathing rate of $1.38 \mathrm{~m}^{3} \mathrm{hr}^{-1}$ was selected to represent an average adult during light activity (light activity defined as walking at speed level 1.5-3.0 mph) (U.S. EPA, 2011). Potential inhalation exposure of a bystander was calculated over a 30-minute period excluding ambient levels and based on an average nebulisation for $\mathrm{V}_{\mathrm{t}}=820 \mathrm{~mL}$ and $\mathrm{V}_{\mathrm{t}}=270 \mathrm{~mL}$. The breathing rate of $0.54 \mathrm{~m}^{3} \mathrm{hr}^{-1}$ was selected to represent an average adult during sedentary activity (sedentary activity defined as sitting and standing) (U.S. EPA, 2011).

\section{Data Analysis and Statistics}

Data analysis for this study was performed using statistical package Minitab 17.0 (Minitab, Pennsylvania, USA). Summary and descriptive statistics were performed on the aerosol concentrations. All distribution data from aerosol measurements are summarised using median and interquartile range (IQR) values. Due to the nonparametric nature of the data, an analysis of variance (the KruskalWallis test) was performed to test for significance between runs. Differences between runs were considered statistically significant when $\mathrm{p}<0.05$.

\section{RESULTS}

Ambient aerosol mass concentrations in the room prior to nebulisation were recorded as $0.006(0.004,0.008) \mathrm{mg} \mathrm{m}^{-3}$. 


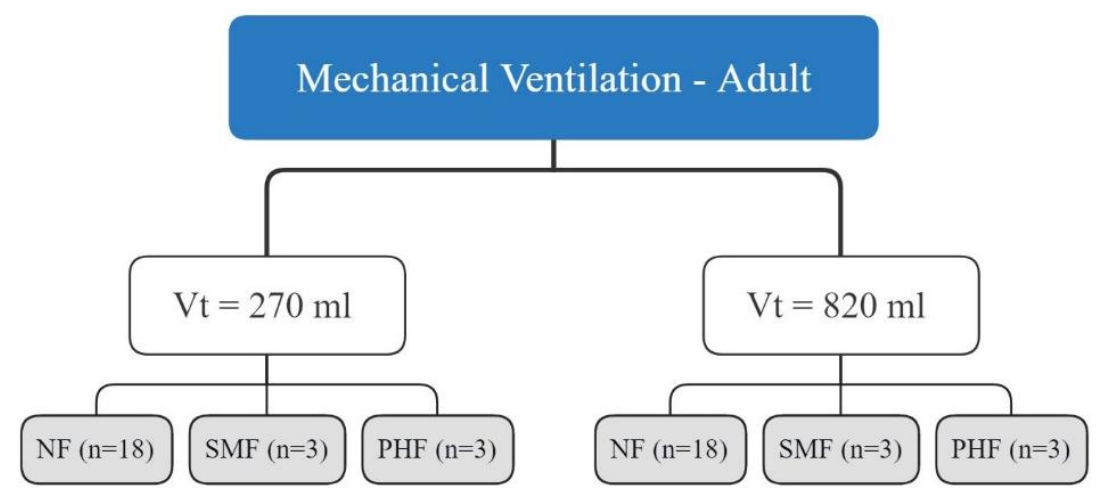

Fig. 2. Flow chart of parameters tested during the study. Tidal volume $\left(\mathrm{V}_{\mathrm{t}}\right)$ of 270 and $820 \mathrm{~mL}$ tested with No Filter (NF), Single membrane filter - Respirgard (SMF) \& Pleated Hydrophobic filter - Pall (PHF).

Average temperature and relative humidity for the duration of the experiments was $18.6 \pm 0.9^{\circ} \mathrm{C}$ and $40.3 \pm 8.6 \%$ respectively.

\section{Absence of Filter}

When there was No Filter (NF) on the exhalation port of the mechanical ventilator, aerosol mass concentrations increased during the nebulisation period (between 5 and 15 minutes) (Fig. 3). The concentration started to increase at 5 minutes, reaching a maximum at 13 minutes (Fig. 3) highlighting the cumulative build-up due to the release of particles from the circuit. At a tidal volume of $820 \mathrm{~mL}$, higher aerosol mass concentrations were emitted into the environment than at $270 \mathrm{~mL},(0.077(0.073,0.091)$ vs. 0.062 $(0.056,0.065) \mathrm{mg} \mathrm{m}^{-3}(\mathrm{p}<0.001)$ at $0.8 \mathrm{~m}$ for NF scenario) as per Fig. 3. After the nebulisation period of approximately 10 minutes, there was a decline in the aerosol mass concentration detected by the APS. During the decay period, there was an average difference of $0.023(0.020,0.027)$ $\mathrm{mg} \mathrm{m}^{-3}$ between 15-30 minutes for the time-series measurements of the two tidal volumes (Fig. 3). The APS at $0.8 \mathrm{~m}$ from the exhalation port of the mechanical ventilator detected higher aerosol mass concentrations consistently for each measurement compared to the APS located at a distance of $2.0 \mathrm{~m}$ when no filter is present on the exhalation port (Table 1 and Fig. 4).

The MMAD during the pre-nebulisation period $(0$ 5 minutes) reflects ambient aerosol mass concentrations within the room. The MMAD during the nebulisation phase (5-15 minutes) was $1.07 \mu \mathrm{m}$ (Geometric standard deviation (GSD) 1.59) for $\mathrm{V}_{\mathrm{t}}=270 \mathrm{~mL}$ and $1.12 \mu \mathrm{m}$ (GSD 1.57) for $\mathrm{V}_{\mathrm{t}}=820 \mathrm{~mL}$ at $0.8 \mathrm{~m}$ (Table 2). During nebulisation, the MMAD significantly decreased compared to pre-nebulisation values for both tidal volumes for the no filter scenario $(\mathrm{p}<$ 0.001 and $\mathrm{p}<0.001$ ) (Table 2).

Particle number concentration data are shown in Table 3 and Fig. 5, and analysis reveals that number concentration was statistically significantly higher for larger tidal volumes (247.54 (230.62, 272.77) \# cm ${ }^{-3}$ vs 282.84 (266.33, 308.91) $\# \mathrm{~cm}^{-3}$ at $\mathrm{V}_{\mathrm{t}}=270 \mathrm{~mL}$ and $\left.\mathrm{V}_{\mathrm{t}}=820 \mathrm{~mL}(\mathrm{p}=0.006)\right)$. Particle concentration increased slightly at a distance of $2.0 \mathrm{~m}$ from the ventilator setup, compared to a distance of $0.8 \mathrm{~m}$ but was not statistically significant $\left(282.84(266.33,308.91) \# \mathrm{~cm}^{-3}\right.$ vs. $297.27(267.09,309.03) \# \mathrm{~cm}^{-3}$ at $\mathrm{V}_{\mathrm{t}}=820 \mathrm{~mL}$ ) (See Table 3 and Fig. 6). To elucidate the data presented in Fig. 4, Figs. 7(a) and 7(b) show a size distribution comparison of fugitive aerosol at the $0.8 \mathrm{~m}$ and $2.0 \mathrm{~m}$ distances, with one plot for each tidal volume scenario. In each plot, it can be seen that the median diameter of the particles reaching the $2.0 \mathrm{~m}$ distance is less than that recorded at the $0.8 \mathrm{~m}$ distance. Specifically, for $\mathrm{V}_{\mathrm{t}}=270 \mathrm{~mL}$, the count median diameter is $0.77 \mu \mathrm{m}$ (GSD 1.29) at $0.8 \mathrm{~m}$ and $0.72 \mu \mathrm{m}$ (GSD $1.27)$ at $2.0 \mathrm{~m}$. For $\mathrm{V}_{\mathrm{t}}=870 \mathrm{~mL}$, the count median diameter is $0.78 \mu \mathrm{m}$ (GSD 1.31) at $0.8 \mathrm{~m}$ and $0.73 \mu \mathrm{m}$ (GSD 1.29) at $2.0 \mathrm{~m}$.

Potential exposure of a healthcare worker while administering drug to a single patient during nebulisation was calculated as $2.53 \%$ of the original drug during the no filter scenario at $\mathrm{V}_{\mathrm{t}}=820 \mathrm{~mL}$ at $0.8 \mathrm{~m}$ and $1.89 \%$ during the no filter scenario at $\mathrm{V}_{\mathrm{t}}=270 \mathrm{~mL}$ at $0.8 \mathrm{~m}$ (Fig. 3). Potential exposure of a bystander while in the vicinity of a patient receiving respiratory therapy during nebulisation was calculated as $0.81 \%$ of the original drug during the no filter scenario at $\mathrm{V}_{\mathrm{t}}=820 \mathrm{~mL}$ at $2.0 \mathrm{~m}$ and $0.63 \%$ during the $\mathrm{NF}$ scenario at $\mathrm{V}_{\mathrm{t}}=270 \mathrm{~mL}$ at $2.0 \mathrm{~m}$ (Fig. 3).

\section{Filter}

Two different filter scenarios were employed to investigate whether placement of a filter on the exhalation port reduced the fugitive emissions from the mechanical ventilator, and if so, whether the effect differed between the two filters. As shown in Table 1 and Fig. 3, higher mass concentrations were recorded with $\mathrm{NF}$ on the mechanical ventilator at $\mathrm{V}_{\mathrm{t}}=$ $270 \mathrm{~mL}$, compared to the SMF or the PHF. At $\mathrm{V}_{\mathrm{t}}=820 \mathrm{~mL}$, a higher aerosol mass concentration was also observed with $\mathrm{NF}$ on the mechanical ventilator than when a filter was placed on the mechanical ventilator (Table 1 and Fig. 3).

There was a statistically significance difference $(\mathrm{p}=$ 0.007) when comparing the average mass concentrations for the NF vs SMF scenario and the NF vs PHF scenario at a low and high tidal volume at $0.8 \mathrm{~m}$. There was a statistically significant difference $(\mathrm{p}=0.05)$ when comparing the average mass concentrations for the SMF scenario for low and high tidal volume at $0.8 \mathrm{~m}$. There was no statistical significance $(p=0.275)$ when comparing the average mass concentrations for the PHF scenario for low and high tidal volume at $0.8 \mathrm{~m}$. 


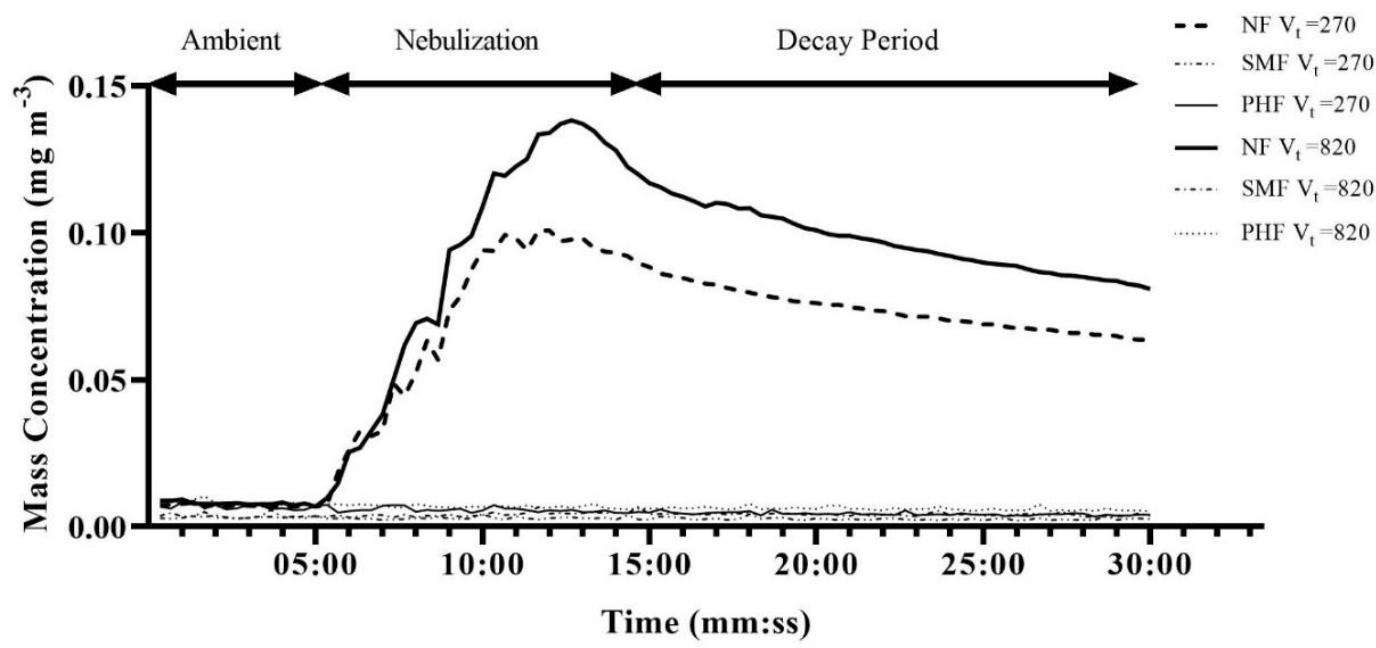

Fig. 3. Average aerosol concentrations for all runs over a 30 -minute period at $0.8 \mathrm{~m}$ from the mechanical ventilator comparing different filters at high and low tidal volumes.

Table 1. Median (IQR) aerosol mass concentrations for a 30-minute period at two tidal volumes.

\begin{tabular}{lllll}
\hline Filter Scenario & $\begin{array}{l}\mathrm{V}_{\mathrm{t}}=270 \mathrm{~mL} \text { at } 0.8 \mathrm{~m} \\
\left(\mathrm{mg} \mathrm{m}^{-3}\right)\end{array}$ & $\begin{array}{l}\mathrm{V}_{\mathrm{t}}=820 \mathrm{~mL} \text { at } 0.8 \mathrm{~m} \\
\left(\mathrm{mg} \mathrm{m}^{-3}\right)\end{array}$ & $\begin{array}{l}\mathrm{V}_{\mathrm{t}}=270 \mathrm{~mL} \text { at } 2.0 \mathrm{~m} \\
\left(\mathrm{mg} \mathrm{m}^{-3}\right)\end{array}$ & $\begin{array}{l}\mathrm{V}_{\mathrm{t}}=820 \mathrm{~mL} \text { at } 2.0 \mathrm{~m} \\
\left(\mathrm{mg} \mathrm{m}^{-3}\right)\end{array}$ \\
\hline NF & $0.062(0.056,0.065)$ & $0.077(0.073,0.091)$ & $0.053(0.051,0.056)$ & $0.067(0.061,0.072)$ \\
SMP & $0.003(0.003,0.003)$ & $0.004(0.003,0.005)$ & $0.002(0.002,0.002)$ & $0.003(0.002,0.003)$ \\
PHF & $0.004(0.004,0.006)$ & $0.006(0.006,0.008)$ & $0.003(0.003,0.004)$ & $0.004(0.004,0.005)$ \\
\hline
\end{tabular}

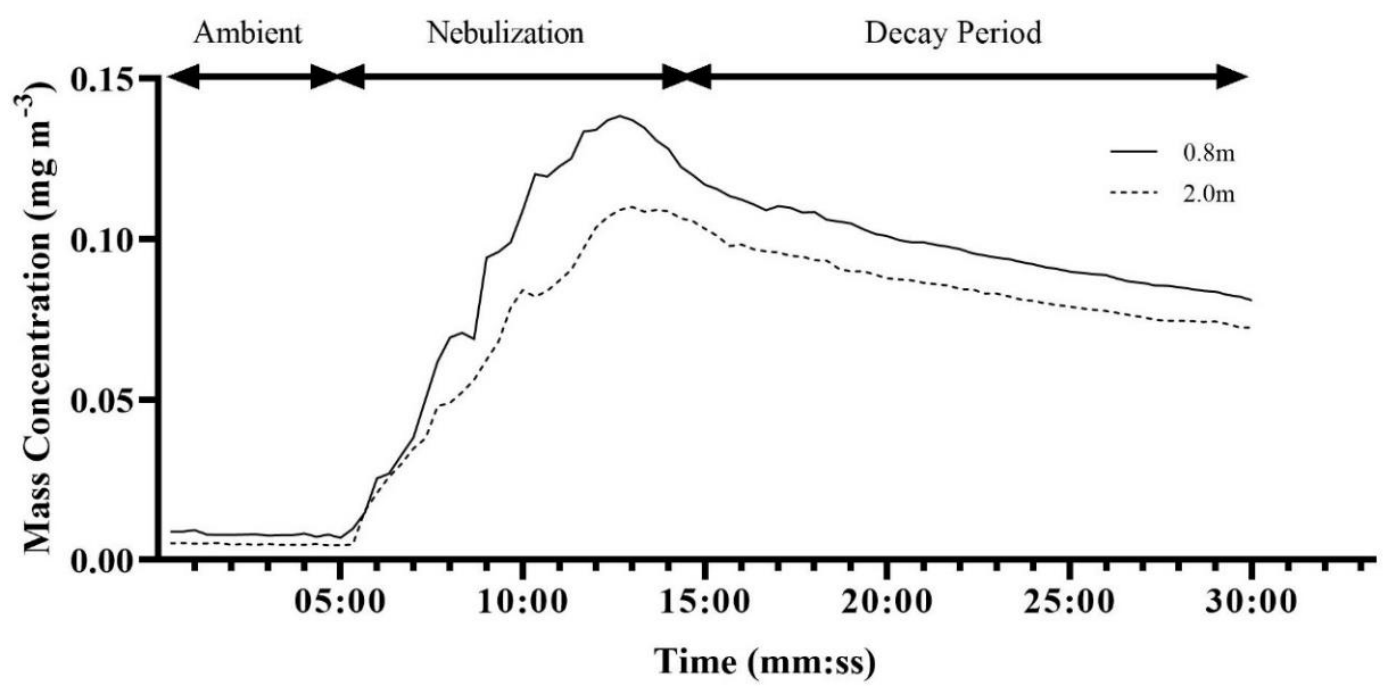

Fig. 4. Average aerosol concentrations across all runs over a 30 minute period at $V_{t}=820 \mathrm{~mL}$ with no filter at the exhalation port of the mechanical ventilator, comparing $0.8 \mathrm{~m}$ and $2.0 \mathrm{~m}(\mathrm{n}=18)$.

Table 2. Median (IQR) MMAD $(\mu \mathrm{m})$ pre-nebulisation (0-5 minutes), during nebulisation (5-15 minutes) and post nebulisation (15-30 minutes) for $\mathrm{V}_{\mathrm{t}}=270 \mathrm{~mL}$ and $\mathrm{V}_{\mathrm{t}}=820 \mathrm{~mL}$ at $0.8 \mathrm{~m}$.

\begin{tabular}{lllllll}
\hline Filter Scenario & MMAD $(\mu \mathrm{m})$ & pre-nebulisation & \multicolumn{2}{l}{ MMAD $(\mu \mathrm{m})$ during nebulisation } & \multicolumn{2}{l}{ MMAD $(\mu \mathrm{m})$ post nebulisation } \\
\hline $\mathrm{V}_{\mathrm{t}}$ & $270 \mathrm{~mL}$ & $820 \mathrm{~mL}$ & $270 \mathrm{~mL}$ & $820 \mathrm{~mL}$ & $270 \mathrm{~mL}$ & $820 \mathrm{~mL}$ \\
\hline $\mathrm{NF}$ & 2.24 & 2.46 & 1.07 & 1.12 & 0.93 & 0.98 \\
& $(2.20,2.57)$ & $(2.05,2.75)$ & $(1.03,1.17)$ & $(1.07,1.18)$ & $(0.92,0.95)$ & $(0.97,1.00)$ \\
$\mathrm{SMP}$ & 2.48 & 2.96 & 2.09 & 2.02 & 2.25 & 1.59 \\
& $(2.07,3.44)$ & $(2.51,3.16)$ & $(1.97,2.19)$ & $(1.88,2.60)$ & $(1.91,2.29)$ & $(1.43,1.64)$ \\
$\mathrm{PHF}$ & 2.65 & 1.92 & 2.51 & 1.85 & 2.26 & 1.93 \\
& $(1.80,3.04)$ & $(1.85,2.06)$ & $(1.72,2.52)$ & $(1.82,1.94)$ & $(1.60,2.30)$ & $(1.87,2.13)$ \\
\hline
\end{tabular}


Table 3. Median (IQR) particle number concentrations for a 30-minute period at two tidal volumes.

\begin{tabular}{lllll}
\hline Filter Scenario & $\begin{array}{l}\mathrm{V}_{\mathrm{t}}=270 \mathrm{~mL} \text { at } 0.8 \mathrm{~m} \\
\left(\# \mathrm{~cm}^{-3}\right)\end{array}$ & $\begin{array}{l}\mathrm{V}_{\mathrm{t}}=820 \mathrm{~mL} \text { at } 0.8 \mathrm{~m} \\
\left(\# \mathrm{~cm}^{-3}\right)\end{array}$ & $\begin{array}{l}\mathrm{V}_{\mathrm{t}}=270 \mathrm{~mL} \text { at } 2.0 \mathrm{~m} \\
\left(\# \mathrm{~cm}^{-3}\right)\end{array}$ & $\begin{array}{l}\mathrm{V}_{\mathrm{t}}=820 \mathrm{~mL} \text { at } 2.0 \mathrm{~m} \\
\left(\# \mathrm{~cm}^{-3}\right)\end{array}$ \\
\hline NF & $247.54(230.62,272.77)$ & $282.84(266.33,308.91)$ & $263.17(251.39,271.57)$ & $297.27(267.09,309.03)$ \\
SMP & $8.42(6.17,8.83)$ & $10.25(7.39,10.99)$ & $9.06(6.54,9.49)$ & $11.45(8.07,11.50)$ \\
PHF & $4.47(4.01,5.67)$ & $6.62(5.76,7.20)$ & $4.48(4.03,5.66)$ & $6.46(5.69,7.01)$ \\
\hline
\end{tabular}

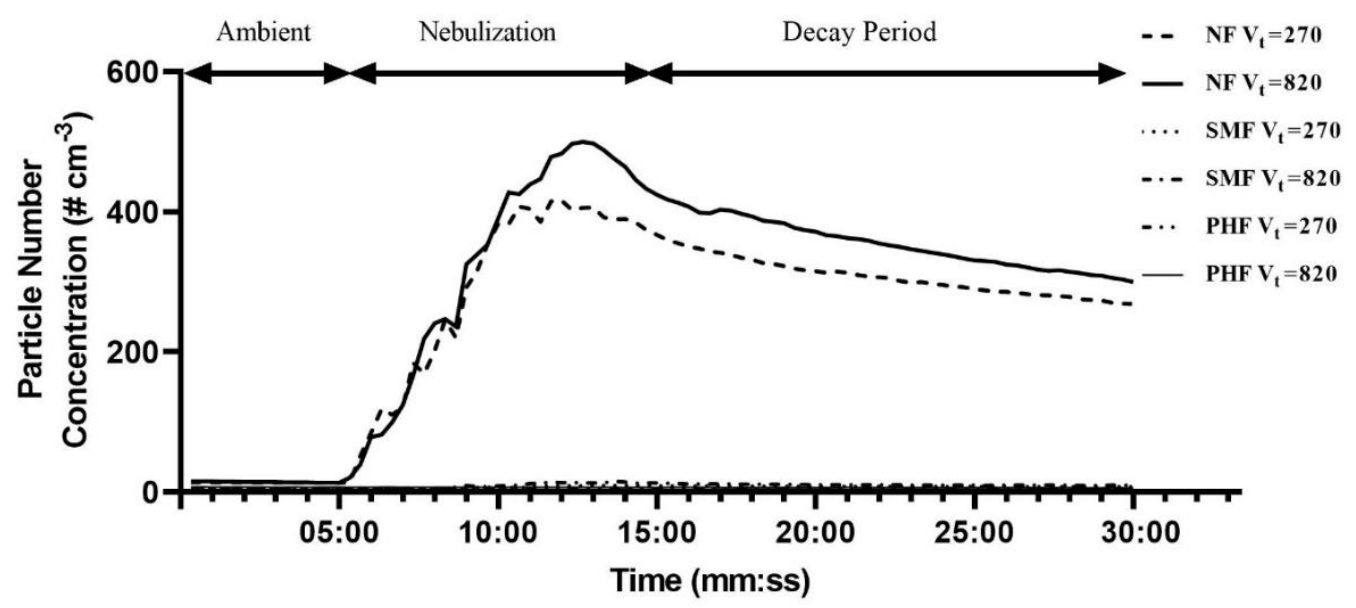

Fig. 5. Average particle number concentrations for all runs over a 30-minute period at $0.8 \mathrm{~m}$ from the mechanical ventilator comparing different filters at high and low tidal volumes.

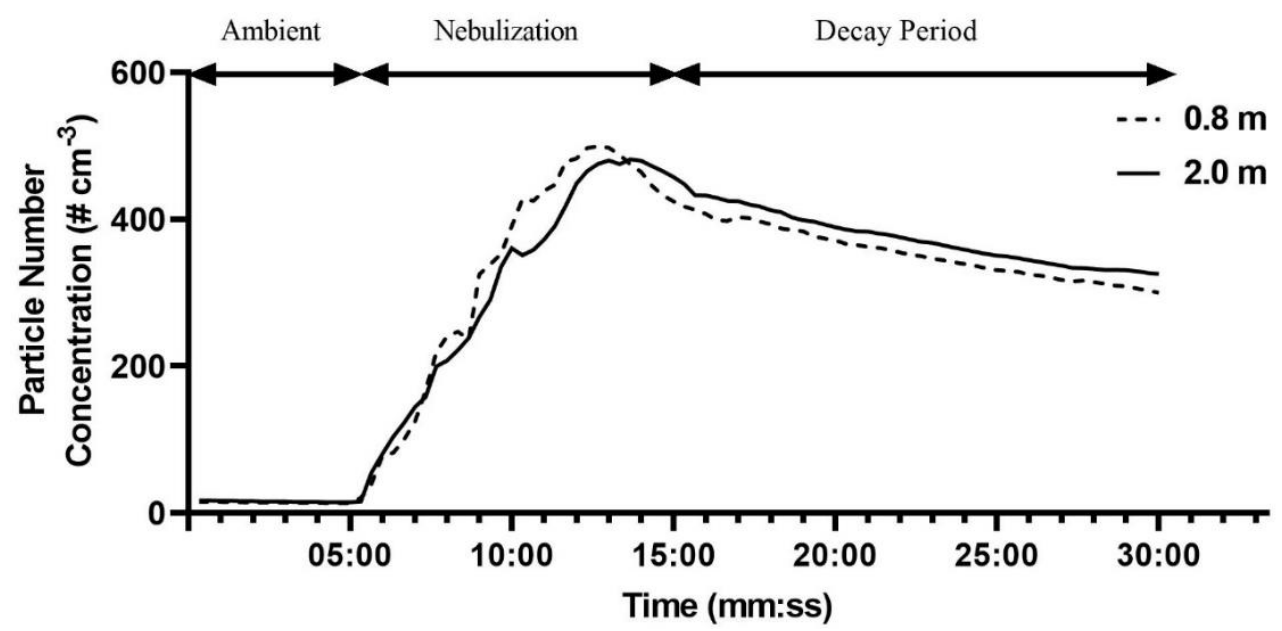

Fig. 6. Average particle number concentrations across all runs over a 30 minute period at $\mathrm{V}_{\mathrm{t}}=820 \mathrm{~mL}$ with no filter at the exhalation port of the mechanical ventilator, comparing $0.8 \mathrm{~m}$ and $2.0 \mathrm{~m}(\mathrm{n}=18)$.

There was a statistically significant difference $(p=0.05)$ when comparing the average mass concentrations for the PHF vs SMF scenario for low tidal volume. There was no statistical significance found $(\mathrm{p}=0.127)$ when comparing the average mass concentrations for the PHF vs SMF scenario for high tidal volume.

In relation to MMAD, there was no significant difference between pre nebulisation levels and nebulisation levels for the two filtered scenarios $\left(\mathrm{p}=0.723\right.$ and $\mathrm{p}=0.443$ for $\mathrm{V}_{\mathrm{t}}=$ $270 \mathrm{~mL}$ and $\mathrm{p}=0.469$ and $\mathrm{p}=0.634$ for $\mathrm{V}_{\mathrm{t}}=820 \mathrm{~mL}$, see Table 2). From Table 3 and Figs. 5 and 6, particle number concentration did not vary when comparing various distances or tidal volumes for the filtered scenario.

\section{DISCUSSION}

The current research, an aerosol analysis study, adds to the current state of the art knowledge surrounding the impact of tidal volume and exhalation filter on fugitive emissions during mechanical ventilation. The main findings of this study were that the use of a filter on the exhalation port of the mechanical ventilator is important in reducing emissions to ambient levels, and that concentration and size characteristics of fugitively-emitted aerosol are dependent on the proximity of a HCW worker to a patient. Additionally, it was demonstrated that tidal volume has a significant impact on fugitive emissions in the absence of an exhalation port filter. 
(a)

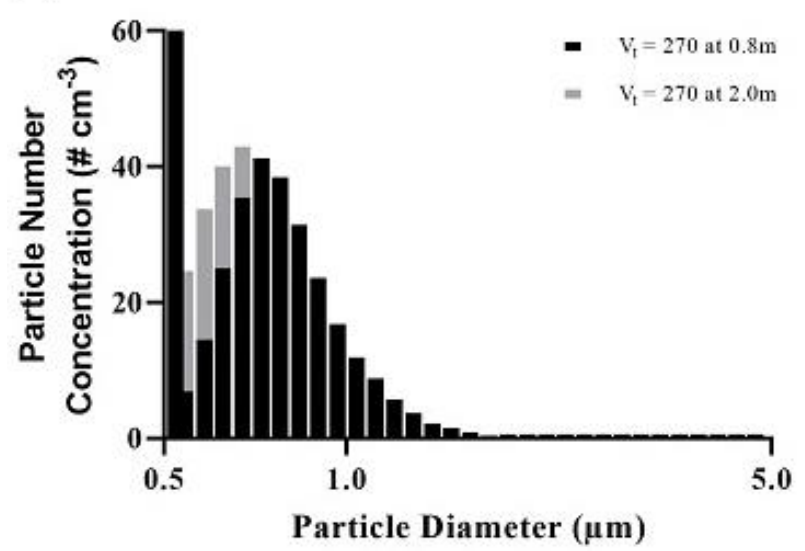

(b)

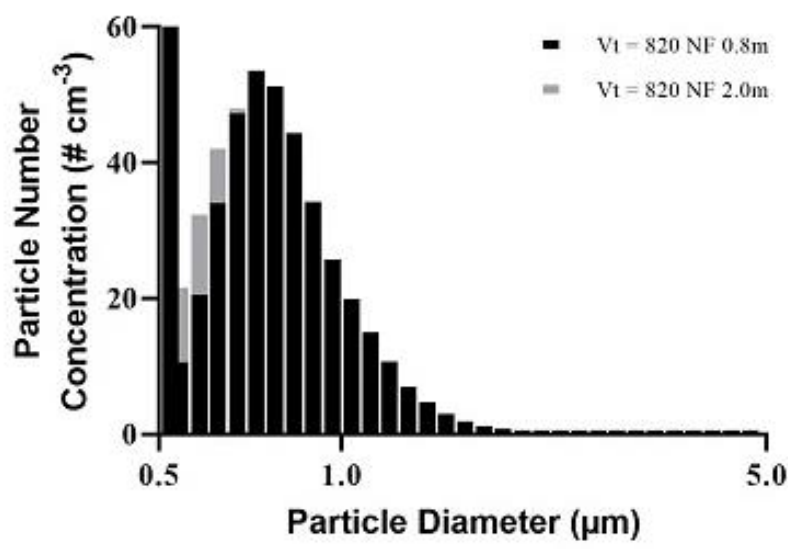

Fig. 7. Size distributions of a single representative run at 13 minutes (peak nebulisation) of aerosol particles at $0.8 \mathrm{~m}$ and $2.0 \mathrm{~m}$ for the no filter scenarios at (a) $\mathrm{V}_{\mathrm{t}}=270 \mathrm{~mL}$ and (b) $\mathrm{V}_{\mathrm{t}}=820 \mathrm{~mL}$.

\section{Absence of Filter}

At $\mathrm{V}_{\mathrm{t}}=820 \mathrm{~mL}$, significantly $(\mathrm{p}<0.001)$ higher aerosol mass concentrations were emitted into the environment compared to $\mathrm{V}_{\mathrm{t}}=270 \mathrm{~mL}$ (Fig. 3). This is due to the change in air volume expelled from the mechanical ventilator, which affects the flow rate and increases the velocity of the aerosol, and therefore the distance at which fugitive aerosols may be detected from the mechanical ventilator (Silvestri, 2006). After nebulisation, mass concentrations declined. This decay is due to air exchange and/or deposition of aerosol within the room (Smolik et al., 2005). From Figs. 3 and 4 , it can be seen that more than 30 minutes is required for the room's aerosol concentration to return to ambient levels. This is dependent on a number of local factors, one of which is the air change rate in the room. Oilier et al. (2019) varied the air change rate in the room and observed that this parameter was the most effective measure for reducing potential exposure to healthcare workers.

Particle number concentration increased significantly with increasing tidal volume in the absence of a filter. This increase can be explained due to a greater volume of air, resulting in more particles being exhaled from the patient. Wan et al. (2014) investigated the relationship between exhaled breath particles and tidal volume in an ICU and found that when mechanically ventilated patients coughed, high concentrations of exhaled particles were produced and that tidal volume was not linked to exhaled breath particle concentration. However, a previous study has reported the opposite for spontaneously breathing patients (Schwarz et al., 2010). From the current study's findings, tidal volume was found to have an effect on fugitive emissions under certain respiratory therapy conditions and therefore it is recommended that exhalation port filters should be used to negate this effect; the ability of filters to significantly reduce emissions was also confirmed in the current research.

At a distance of $0.8 \mathrm{~m}$ from the ventilator, higher aerosol mass concentrations were found consistently for each measurement compared to the $2.0 \mathrm{~m}$ distance, in line with previous studies (McGrath et al., 2019a, b). Interestingly, when comparing Figs. 4 and 6, there is a clear difference in mass concentration between the two distances but there is no apparent difference between number concentrations when comparing the same distances. The larger MMAD at the $0.8 \mathrm{~m}$ compared to $2.0 \mathrm{~m}$ accounts for the higher mass concentrations even though the number concentrations are similar. This shows that at greater distances, less aerosol mass is present (this is borne out by size distribution data shown in Fig. 7, which indicate particles of larger median diameter at $0.8 \mathrm{~m}$ distance, compared with $2.0 \mathrm{~m}$ distance) and this knowledge can inform policy on hospital bed spacing and visitor positioning. The observed decrease in larger particle transport with distance can be attributed to a range of factors, including deposition and localised airflow effects; additionally, the findings of Elmashae et al. (2019) suggest that evaporation could also be a consideration, and this may merit investigation in a future study.

Preliminary calculations show that a $\mathrm{HCW}$ administering drug to a mechanically ventilated patient, where no filter is used at the exhalation port, could, at average mass concentrations, inhale up to $2.53 \%$ of the original drug. This is a conservative calculation, as a HCW may stay by a patient's bedside for more or less than 30 minutes, depending on the severity of the patient's illness. Additional patients present in the room also receiving nebulisation therapy may result in further cumulative build-up of fugitive emissions, resulting in increased potential inhalation exposure to HCWs. Potential bystander exposure during a 30-minute period was calculated as $0.81 \%$ of the nominal dose originally placed in the nebuliser. This confirms an estimation by McGrath et al. (2019b) (in a laboratory simulation of fugitive aerosol exposure during therapies involving nasal cannula and tracheostomy at a low air change rate) of the risk of inhaling drug by $\mathrm{HCWs}$ and bystanders present during respiratory therapy. However, it is also important to note that the measured particle sizes rest within the recognised range of potential patient-derived bioaerosol sizes (Liu et al., 2020).

\section{Filter}

The current data demonstrate that the use of a filter, when placed at the exhalation port, can have a beneficial effect in 
reducing secondary emitted aerosols. This information may be relevant for a wide range of nebulised drugs e.g., acetylcysteine, a specific mucolytic ( $\mathrm{Hu}$ et al., 2015) or antibiotics such as colistin (Liu et al., 2019). It may also be beneficial to inform physicians who interact with patients on mechanical ventilators. In the current study, the presence of a filter at the exhalation port prevented emission of medical aerosol, with only ambient levels detected (Table 1). In a study by Ari (2016), it was calculated that $40.6 \pm 0.21 \%$ and $45.1 \pm 5.1 \%$ of the nominal dose was delivered to the environment when only an exhaust filter was placed on two different mechanical ventilators. These observed percentages are greater than found in the current study due to differing methods of collection. In the study by Ari (2016), the basis was a filter mass measurement, from which it was assumed that all material on the filter could potentially be released into the environment. In the current study, however, actual fugitive aerosol measurements were made and hence the calculated exposures are much lower $(2.53 \%$ for $\mathrm{HCW}$ and $0.81 \%$ for bystander).

While there was a statistically significant difference in emitted aerosol mass concentrations between the no filtered scenarios at the two tidal volumes, there was also a significance found when comparing the $V_{t}=270 \mathrm{~mL} \mathrm{SMF}$ case with both PHF scenarios. As the experiments were carried out over a number of days, there were fluctuating ambient levels within the dataset, and this may explain the above observations (See Tables 2 and 3). Also, it was not possible to accurately compared between $n=18$ vs. $n=3$ due to the differences in the sample sizes. While there is a statistical significance, there is no practical difference as shown from the above trends between filters based on the results (Fig. 3).

From Table 1, there is no clear trend in fugitive emissions, according to which filter scenario was used. Data indicates less potential for exposure to fugitive emissions for bystanders and healthcare workers with aerosol concentrations at ambient levels when a filter is placed on the mechanical ventilator. Potential exposure for the filtered scenarios was not included because using a filter resulted in only ambient levels being detected therefore, indicating minimal to no exposure. These findings support the often-ignored recommendation for placement of a filter on the expiratory limb of the circuit (Fink et al., 2020). In one survey, 65\% of physicians reported using a filter on the mechanical ventilator but of those, $28 \%$ never changed it (Ehrmann et al., 2013). This demonstrates that while filters should be widely used, and regularly changed, in some cases they are not, even though they reduce fugitive emissions and protect the mechanical ventilator (Ehrmann et al., 2013).

\section{Limitations}

While this study provides insight on fugitive emissions during mechanical ventilation, there are limitations. The study used one type of nebuliser, but acknowledges that various nebulisers are used in clinical practice, and emissions may vary depending on nebuliser type. Nevertheless, the nebuliser used, is the only currently available closed circuit nebuliser. However, it can be noted that many of the findings in this paper are comparative (i.e., different filter scenarios, different tidal volumes) but the nebuliser is a constant throughout the study. Ideally, trials conducted in a clinical setting would be of greater benefit but this bench study provides an indication of potential emissions. The low room air change rate could be seen as a limiting factor if results were to be compared to a hospital setting with a larger air change rate but it can be noted that mechanical ventilator usage is not uncommon in longer-term care facilities with lower air exchange rates (Lloyd-Owen et al., 2005). It should be noted that the APS has a limit of detection of $0.5 \mu \mathrm{m}$, and for this reason, both number and mass concentration data have been include in this work, so as to reflect the smaller end of the particle size distribution as fully as possible. One of the main aims of this work was estimating fugitively-emitted drug exposure, and large particles have the greatest influence in this regard. However, for other applications, future work may need to consider using aerosol measurement instruments that can extend further into the sub-micrometre range.

\section{CONCLUSION}

This study confirms that aerosols have the potential to be emitted during mechanical ventilation, should protective filters not be used. The effect of higher tidal volumes leading to greater quantities of fugitive emissions being released to the local environment is demonstrated. It is recommended that, where practical, an appropriate filter be placed at the exhalation port of the mechanical ventilator, as this significantly reduces emissions. Finally, whilst not directly assessed here, these findings hold relevance in the protection against patient-derived bioaerosols, which may present a disease transmission risk.

Further work is required in this area with a view to informing healthcare professionals as to the most appropriate measure to adopt in order to mitigate the risk of exposure to either fugitive medical aerosols or patient-derived bioaerosols.

\section{ACKNOWLEDGEMENTS}

This work represents research funded by the Irish Research Council under the Government of Ireland Postgraduate Scholarship Programme - GOIPG/2018/1968.

\section{DISCLAIMER}

Mary Joyce, Gavin Bennett and Ronan MacLoughlin are employees of Aerogen Limited. Ciarraí O'Toole, James McGrath and Miriam Byrne have no conflicts of interest.

\section{REFERENCES}

Aerogen Ltd. (2016). Aerogen solo system instruction manual. https://www.aerogen.com/wp-content/uploads/2 016/03/30-674-Rev-G-Aerogen-Solo-System-IM-USWEB.pdf

American Association for Respiratory Care (2020). SARS CoV-2. https://www.aarc.org/wp-content/uploads/2020/0 3/guidance-document-SARS-COVID19.pdf 
Ari, A., Atalay, O.T., Harwood, R., Sheard, M.M., Aljamhan, E.A. and Fink, J.B. (2010). Influence of nebulizer type, position, and bias flow on aerosol drug delivery in simulated pediatric and adult lung models during mechanical ventilation. Respir. Care 55: 845-851.

Arif, A.A., Delclos, G.L. and Serra, C. (2009). Occupational exposures and asthma among nursing professionals. Occup. Environ. Med. 66: 274-278. https://doi.org/10.11 36/oem.2008.042382

Berlinski, A. and Velasco, J. (2019). Albuterol delivery efficiency in a pediatric model of noninvasive ventilation with a single-limb circuit. Respir. Care 64: 1366-1370. https://doi.org/10.4187/respcare.06622

Berlinski, A. and Willis, J.R. (2013). Albuterol delivery by 4 different nebulizers placed in 4 different positions in a pediatric ventilator in vitro model. Respir. Care 58: 1124 1133. https://doi.org/10.4187/respcare.02074

Chughtai, A.A., Seale, H. and Macintyre, C.R. (2013). Availability, consistency and evidence-base of policies and guidelines on the use of mask and respirator to protect hospital health care workers: A global analysis. BMC Res. Notes 6: 216. https://doi.org/10.1186/1756-0500-6-216

Cinesi Gómez, C., Peñuelas Rodríguez, Ó., Luján Torné, M.L., Egea Santaolalla, C., Masa Jiménez, J.F., García Fernández, J., Carratalá Perales, J.M., Heili-Frades, S.B., Ferrer Monreal, M., de Andrés Nilsson, J.M., Lista Arias, E., Sánchez Rocamora, J.L., Garrote, J.I., Zamorano Serrano, M.J., González Martínez, M., Farrero Muñoz, E., Mediano San Andrés, O., Rialp Cervera, G., Mas Serra, A., Hernández Martínez, G., de Haro López, C., Roca Gas, O., Ferrer Roca, R., Romero Berrocal, A. and Ferrando Ortola, C. (2020). Clinical consensus recommendations regarding non-invasive respiratory support in the adult patient with acute respiratory failure secondary to SARSCoV-2 infection. Rev. Esp. Anestesiol. Reanim. 67: 261-270. https://doi.org/10.1016/j.redar.2020.03.006

Cook, T.M., El-Boghdadly, K., McGuire, B., McNarry, A.F., Patel, A. and Higgs, A. (2020). Consensus guidelines for managing the airway in patients with COVID-19. Anaesthesia 75: 785-799. https://doi.org/10.1111/anae.1 5054

Demers, R.R., Burciaga, C. and Sousa, M. (2016). The Respirgard II 303 breathing circuit filter is NOT an "absolute filter". Respir. Care 61: 1710-1711. https://doi.org/10.4187/respcare.05234

Dhand, R. (2008). Aerosol delivery during mechanical ventilation: From basic techniques to new devices. $J$. Aerosol Med. Pulm. Drug Deliv. 21: 45-60. https://doi.org/10.1089/jamp.2007.0663

Dugernier, J., Reychler, G., Wittebole, X., Roeseler, J., Depoortere, V., Sottiaux, T., Michotte, J.B., Vanbever, R., Dugernier, T., Goffette, P., Docquier, M.A., Raftopoulos, C., Hantson, P., Jamar, F. and Laterre, P.F. (2016). Aerosol delivery with two ventilation modes during mechanical ventilation: A randomized study. Ann. Intensive Care 6: 73. https://doi.org/10.1186/s13613-016-0169-x

Ehrmann, S., Roche-Campo, F., Sferrazza Papa, G.F., Isabey, D., Brochard, L., Apiou-Sbirlea, G. and For the REVA research network (2013). Aerosol therapy during mechanical ventilation: An international survey. Intensive Care Med. 39: 1048-1056. https://doi.org/10.1007/s0013 4-013-2872-5

Ehrmann, S., Roche-Campo, F., Bodet-Contentin, L., Razazi, K., Dugernier, J., Trenado-Alvarez, J., Donzeau, A., Vermeulen, F., Thévoz, D., Papanikolaou, M., Edelson, A., León Yoshido, H., Piquilloud, L., Lakhal, K., Lopes, C., Vicent, C., Desachy, A., Apiou-Sbirlea, G., Isabey, D., Brochard, L., Reva Research, N. and Group, A.I.S. (2016). Aerosol therapy in intensive and intermediate care units: Prospective observation of 2808 critically ill patients. Intens Care Med. 42: 192-201. https://doi.org/10.1007/s 00134-015-4114-5

Elmashae, Y., Yermakov, M., Frank, E., Benjamin, M., Maier, A., Newman, N., Reponen, T. and Grinshpun, S.A. (2019). Exposure of home-attending healthcare workers to aerosolized medications (simulation study). J. Aerosol Sci. 133: 49-55. https://doi.org/10.1016/j.jaerosci.2019.0 4.006

Fink, J.B., Ehrmann, S., Li, J., Dailey, P., McKiernan, P., Darquenne, C., Martin, A.R., Rothen-Rutishauser, B., Kuehl, P.J., Haussermann, S., MacLoughlin, R., Smaldone, G.C., Muellinger, B., Corcoran, T.E. and Dhand, R. (2020). Reducing aerosol-related risk of transmission in the era of covid-19: An interim guidance endorsed by the international society of aerosols in medicine. J. Aerosol Med. Pulm. Drug Deliv. https://doi.org/10.1089/jamp.20 20.1615

Frank, E., Ishau, S., Maier, A., Reutman, S. and Reichard, J.F. (2019). An occupational exposure limit (OEL) approach to protect home healthcare workers exposed to common nebulized drugs. Regul. Toxicol. Pharmacol. 106: 251-261. https://doi.org/10.1016/j.yrtph.2019.04.021

Guerin, C., Fassier, T., Bayle, F., Lemasson, S. and Richard, J.C. (2008). Inhaled bronchodilator administration during mechanical ventilation: How to optimize it, and for which clinical benefit? J. Aerosol Med. Pulm. Drug Deliv. 21: 85-96. https://doi.org/10.1089/jamp.2007.0630

Hu, H.C., Liu, H.C., Chen, Y.H., Huang, C.C., Wan, G.H., Chou, L.T., Hsieh, M.J., Chen, N.H., Yang, C.T. and Kao, K.C. (2015). The impact of aerosolized mucolytic agents on the airflow resistance of bacterial filters used in mechanical ventilation. J. Formosan Med. Assoc. 114: 717-721. https://doi.org/10.1016/j.jfma.2013.06.010

Hui, D.S., Hall, S.D., Chan, M.T.V., Chow, B.K., Tsou, J.Y., Joynt, G.M., Sullivan, C.E. and Sung, J.J.Y. (2006). Noninvasive positive-pressure ventilation: An experimental model to assess air and particle dispersion. Chest 130: 730-740. https://doi.org/10.1378/chest.130.3.730

Hui, D.S., Chow, B.K., Lo, T., Ng, S.S., Ko, F.W., Gin, T. and Chan, M.T.V. (2015). Exhaled air dispersion during noninvasive ventilation via helmets and a total facemask. Chest 147: 1336-1343. https://doi.org/10.1378/chest.141934

Hui, D.S., Chow, B.K., Lo, T., Tsang, O.T.Y., Ko, F.W., Ng, S.S., Gin, T. and Chan, M.T.V. (2019). Exhaled air dispersion during high flow nasal cannula therapy versus CPAP via different masks. Eur. Respir. J. 53: 1802339. https://doi.org/10.1183/13993003.02339-2018 
ISO (2019). Anaesthetic and Respiratory EquipmentNebulizing Systems and Components. https://standards.i teh.ai/catalog/standards/cen/d84a2db2-3eb9-441a-a8cdbf4164473965/en-iso-27427-2019

Lin, H.L., Fink, J.B., Zhou, Y. and Cheng, Y.S. (2009). Influence of moisture accumulation in inline spacer on delivery of aerosol using metered-dose inhaler during mechanical ventilation. Respir. Care 54: 1336-1341.

Liu, C.Y., Ko, H.K., Fink, J.B., Wan, G.H., Huang, C.C., Chen, Y.C. and Lin, H.L. (2019). Size distribution of colistin delivery by different type nebulizers and concentrations during mechanical ventilation. Pharmaceutics 11: 459. https://doi.org/10.3390/pharmaceutics11090459

Liu, Y., Ning, Z., Chen, Y., Guo, M., Liu, Y., Gali, N.K., Sun, L., Duan, Y., Cai, J., Westerdahl, D., Liu, X., Ho, K.F., Kan, H., Fu, Q. and Lan, K. (2020). Aerodynamic characteristics and RNA concentration of SARS-CoV-2 aerosol in Wuhan hospitals during COVID-19 outbreak. bioRxiv 2020.2003.2008.982637. https://doi.org/10.1101/ 2020.03.08.982637

Lloyd-Owen, S.J., Donaldson, G.C., Ambrosino, N., Escarabill, J., Farre, R., Fauroux, B., Robert, D., Schoenhofer, B., Simonds, A.K. and Wedzicha, J.A. (2005). Patterns of home mechanical ventilation use in europe: Results from the eurovent survey. Eur. Respir. J. 25: 1025-1031. https://doi.org/10.1183/09031936.05.000 66704

MacLoughlin, R.J., Higgins, B.D., Laffey, J.G. and O'Brien, T. (2009). Optimized aerosol delivery to a mechanically ventilated rodent. J. Aerosol Med. Pulm. Drug Deliv. 22: 323-332. https://doi.org/10.1089/jamp.2008.0717

McGrath, J.A., O’Sullivan, A., Bennett, G., O’Toole, C., Joyce, M., Byrne, M.A. and MacLoughlin, R. (2019a). Investigation of the quantity of exhaled aerosols released into the environment during nebulisation. Pharmaceutics 11: 75. https://doi.org/10.3390/pharmaceutics11020075

McGrath, J.A., O’Toole, C., Bennett, G., Joyce, M., Byrne, M.A. and MacLoughlin, R. (2019b). Investigation of fugitive aerosols released into the environment during high-flow therapy. Pharmaceutics 11: 254. https://doi.org/ 10.3390/pharmaceutics11060254

Moraine, J.J., Truflandier, K., Vandenbergen, N., Berre, J., Melot, C. and Vincent, J.L. (2009). Placement of the nebulizer before the humidifier during mechanical ventilation: Effect on aerosol delivery. Heart Lung 38: 435-439. https://doi.org/10.1016/j.hrtlng.2008.12.005

O’Toole, C., Joyce, M., McGrath, J.A., O’Sullivan, A., Byrne, M.A. and MacLoughlin, R. (2020). Fugitive aerosols in the intensive care unit: A narrative review. Ann. Transl.
Med. 2020 https://doi.org/10.21037/atm-20-2280

Oilier, K., Leppanen, M., Wu, B.B., Yermakov, M., Newman, N.C., Reponen, T. and Grinshpun, S.A. (2019). Inhalation exposure and respiratory protection of home healthcare workers administering aerosolized medications (simulation study). Aerosol Air Qual. Res. 19: 937-944. https://doi.org/10.4209/aaqr.2018.10.0366

Rau, J.L., Ari, A. and Restrepo, R.D. (2004). Performance comparison of nebulizer designs: Constant-output, breath-enhanced, and dosimetric. Respir. Care 49: 174179.

Schwarz, K., Biller, H., Windt, H., Koch, W. and Hohlfeld, J.M. (2010). Characterization of exhaled particles from the healthy human lung-a systematic analysis in relation to pulmonary function variables. J. Aerosol Med. Pulm. Drug Deliv. 23: 371-379. https://doi.org/10.1089/jamp.2 009.0809

Silvestri, S. (2006). The influence of flow rate on breathing circuit compliance and tidal volume delivered to patients in mechanical ventilation. Physiol. Meas. 27: 23-33. https://doi.org/10.1088/0967-3334/27/1/003

Smolik, J., Lazaridis, M., Moravec, P., Schwarz, J., Zaripov, S. and Zdimal, V. (2005). Indoor aerosol particle deposition in an empty office. Water Air Soil Pollut. 165: 301-312. https://doi.org/10.1007/s11270-005-7146-6

The Acute Respiratory Distress Syndrome Network (2000). Ventilation with lower tidal volumes as compared with traditional tidal volumes for acute lung injury and the acute respiratory distress syndrome. N. Engl. J. Med. 342: 1301-1308. https://doi.org/10.1056/NEJM20000504342 1801

Tsai, R.J., Boiano, J.M., Steege, A.L. and Sweeney, M.H. (2015). Precautionary practices of respiratory therapists and other health-care practitioners who administer aerosolized medications. Respir. Care 60: 1409-1417. https://doi.org/10.4187/respcare.03817

U.S. EPA (2011). Exposure Factors Handbook 2011 Edition (Final Report). U.S. Environmental Protection Agency, Washington, DC, EPA/600/R-09/052F.

Wan, G.H., Wu, C.L., Chen, Y.F., Huang, S.H., Wang, Y.L. and Chen, C.W. (2014). Particle size concentration distribution and influences on exhaled breath particles in mechanically ventilated patients. PLoS One 9: e87088. https://doi.org/10.1371/journal.pone.0087088

Received for review, April 27, 2020 Revised, September 3, 2020 Accepted, October 3, 2020 